REGULAR ARTICLE

\title{
THE FUTURE OF GRASSLANDS AND BEEF CATTLE IN THE CZECH REPUBLIC
}

\author{
Tomáš Ratinger $^{* 1}$, Miluše Abrahamová ${ }^{2}$, Jan Boudný ${ }^{2}$ Iveta Boškova ${ }^{2}$, Ivan Foltýn ${ }^{2}$, Martin \\ Hruška ${ }^{2}$, Jaroslav Pražan ${ }^{2}$, Václav Voltr²
}

\author{
Address: \\ ${ }^{1}$ Technology Centre of the Academy of Sciences the Czech Republic, Ve struhách 27, 18600 Praha, Czech Republic \\ ${ }^{2}$ Institute for Agricultural Economics and Information, Mánesova 75, 12058 Praha, Czech Republic \\ *Corresponding author: ratinger@tc.cz
}

\begin{abstract}
Grasslands received policy attention in the Czech Republic only just fifteen years ago, when they were threatened to be abandoned in the economic transition process. The supports to farming on grasslands have grown gradually, particularly after the EU accession. The policy followed the notion of jointness between grassland management and beef cattle raising and conditioned Agri-environmental (AE) and Less Favoured Areas (LFA) payments by a minimum livestock density. There are many reasons why the current policy will change in the new programme period. This paper attempts to assess the impact of the envisaged changes on grassland maintenance. It is showed that overall future supports to farming will be sufficient to keep positive profit on grassland farms, however the structure of supports might be less appropriate to the actual objectives of grassland protection and hence, there is a threat of policy failure in the end.
\end{abstract}

Keywords: grasslands, beef cattle, mathematic programming model

JEL: Q20, Q28

\section{INTRODUCTION}

Grasslands received policy attention in the Czech Republic only just fifteen years ago, when they were threatened to be abandoned in the economic transition process. Beef production dropped due to the collapse of demand by $40 \%$ between 1990 and 1995 and consequently cultivation of grasslands as well. From the very beginning, the support to grasslands was linked to extensive beef production. However, there were almost no suckler cows herds before 1995. Raising suckler cows was stimulated by several measures since that, by the minimum livestock density condition for the grasslands maintenance support and LFA payments, specific Top-ups (European Council, 2009), the support to organic beef and a specific investment support. In 2011 (2010), there were 183 thousand (167 thousand) suckler cows, 700 thousand hectares of grasslands under the maintenance support (MoA, 2012). The average of all area supports per hectare of grasslands reached 15 thousand CZK (approximately $€$ $600)$ in 2011. In spite of terrible unprofitability of the extensive beef production, such a support is perceived to be inadequate, generating excessive profits particularly on large extensive farms (Doucha et al. 2012a).

The objective of the paper is to discuss and to assess options of grassland maintenance scheme under CAP 2020 reform (European Commission 2011a; European Commission 2011b). In turn it means: i) to evaluate social and private costs and benefits of the current policy; ii) to discuss the conceptual approach to grasslands maintenance including biodiversity conservation, landscape protection and jointness of them with extensive beef production; iii) to develop scenarios of policy options deploying new and old instruments of Pillar 1 and 2 of the CAP 2020.

The paper is structured in 8 parts. First, the overall approach is presented. Then we discuss the social value of grasslands and after that we give the notion on the distribution of grasslands in the country. The current beef production on grasslands is presented in the following section. It also includes a simple cost benefit analysis. Afterwards we introduce the farm model and the scenarios. These with the results are the core of the paper. The findings are summed up and discussed in the final part.

It is important to stress, that the paper refers to the on-going research and therefore presented results are still to be taken as provisional.

\section{METHODOLOGY}

The cost benefit analysis (Guess, Farnham, 2000) is based on the Farm Accountancy Data Network (FADN) data, the special production costs survey of the Institute of Agricultural Economics and Information (UZEI) of the Czech Republic, beef market data, soil quality database, earlier willingness-to-pay (WTP) and willingness-to-accept (WTA) valuation of landscape, conducted by UZEI and expert knowledge. To assess the scenarios, we applied a regionalised farm model (FARMA-4) based on mathematical programming approach. In the model the number of farm types cultivating grasslands was extended (to 6) for better depiction of various soil and climatic conditions. Each farm type assumes two or more optional production and 
conservation technologies on grasslands (see later). The quantitative analysis is completed by two qualitative case studies.

\section{Value of Grasslands}

Grasslands have a particular value in the Czech Republic, where $71 \%$ of agricultural land accounts for arable land, with grasslands on less than a quarter of it (23\%, MoA, 2012). At the same time, there is quite a high proportion of forests in the country (33.7\% of the national territory, CZSO 2012a). Therefore, there is a need for more grassland from environmental point of view in general. Especially in mountain areas, each meadow is of high ecological value as a factor of diversity of habitats and open space. But grasslands are desirable also in the other parts of the country. A lot of arable fields extend on steep slopes accelerating soil erosion in sub-mountain areas while crop yields are relatively poor. There are fertile areas with small number of landscape features where grassland adds to the ecological stability; etc.

The Czech population highly value the landscape management, which is predominantly comprised by grassland maintenance and provided by farmers. According to the contingence valuation survey carried out by UZEI in 2010 (Wollmuthová, Majerová 2011), the Czech citizens are ready to spend for an additional hectare of grasslands between 167 - 424 EUR (WTP valuation) and accept compensation of 435 - 768 EUR for a hectare lost (WTA) ${ }^{1}$. This survey also showed that the Czech population preferred maintaining the landscape by farmers with the public funds support. The high social value of grasslands is recognised by the law. Grasslands conversion to arable land is very restricted, practically prohibited.

There are two contrasting threats to grasslands: their insufficient management or abandonment in some areas and excessive intensification in the others. The grasslands were threatened by abandonment much more than any other type of land use in the 1990s, when beef and milk markets declined. Nowadays, about a third of the grassland area is cultivated only thanks to supports like direct payments (DP), Less Favoured Area payments (LFA payments) or Agri-environmental measures (AEM). The threat that grasslands are overgrown by shrubs and trees remains if the supports are cancelled or substantially reduced.

Current targeted support to grassland consists of agri-environmental measure, e.g. support of grassland management and payments for grassland management under organic farming in many cases.

\section{Territorial Distribution of Grasslands}

As shoved in Figure 1 grasslands are distributed predominantly in mountain and sub-mountain areas. In general, the higher altitude the higher share of

\footnotetext{
1 WTP - willingness to pay, WTA - willingness to accept (a compensation). The both figures have to be taken with caution, since they are recalculated from the reported figures of willingness of citizens to pay (to accept a compensation), per capita and annually, for landscape maintenance (a loss of it) in districts, where grasslands are the main landscape amenity.
}

grasslands on UAA. The exception is the west and particularly the north-west part of Bohemia, where high shares of grasslands are also in lower altitudes. This is associated with the collapse of farming in these regions after the disruption of state farms ${ }^{2}$.

Yields decline with the altitude too (Figure 2). There are two other factors affecting yields particularly water availability (rains) and application of fertilisers. In western Bohemia, yields are high even in high altitudes, due to more Atlantic climate with sufficient rains. In contrast, the climate is dry and yields are rather poor in east Moravian mountains.

In 2011 UZEI carried out an extensive survey on the grasslands cultivation with focus on application of fertilisers (Pražan et al. 2011). 588 farms with grasslands were interviewed. It revealed that the intensity of input use had been declining significantly since the beginning of the 1990s. The application of nitrogen did not exceeded on average $30 \mathrm{~kg}$ per hectare during the last few years; corresponding yields are substantially below (by 20\%) their potentials. The survey also disclosed relatively insignificant differences in application of fertilizers between farms beneficiaries of support from the agri-environmental measure (grasslands maintenance) and farms non-beneficiaries.

\section{Beef Cattle on Grasslands}

Within a short period beef cattle on grasslands became an important part of domestic cattle herd. In early 1990s cattle herd was completely linked to dairy cows. Suckler cows herd grew significantly and suckler cows share amounted a third of the total cow herd in 2011(Table $1)^{3}$.

Rapid development of the beef herd is to be understood as a consequence of land with poor soil conversion to grasslands. This conversion was supported by the governmental policy and partly by market opportunities which emerged after the accession to the EU market. The suckler cow herd amounted 178 thousand heads in 2011, most of it being located on grasslands (MoA 2012). There is to mention that bull fattening is usually separated from cow-calf farms; the cow-calf farms are typically on grasslands while bull fattening is traditionally in sheds. This pattern has resulted from the earlier production system based on dairy cows as well as from market opportunities for exporting young bulls.

An important feature of cow-calf farms is the organic way of production system. In 2010 almost 80 thousand suckler cows were raised in the organic farms (CZSO, 2012c). To finish the animals on organic cowcalf farm means either to finish them by own silage and hay, or to purchase organic concentrate feeds. Since it is costly in either way, and the high quality beef market is underdeveloped in the Czech Republic, beef finishing by the organic way is rather rare.

\footnotetext{
2 There are also deeper roots in the history, these were areas predominantly populated by Germans. After their exodus, attachment to farming deteriorated.

${ }^{3}$ Note that dairy herd declined.
} 


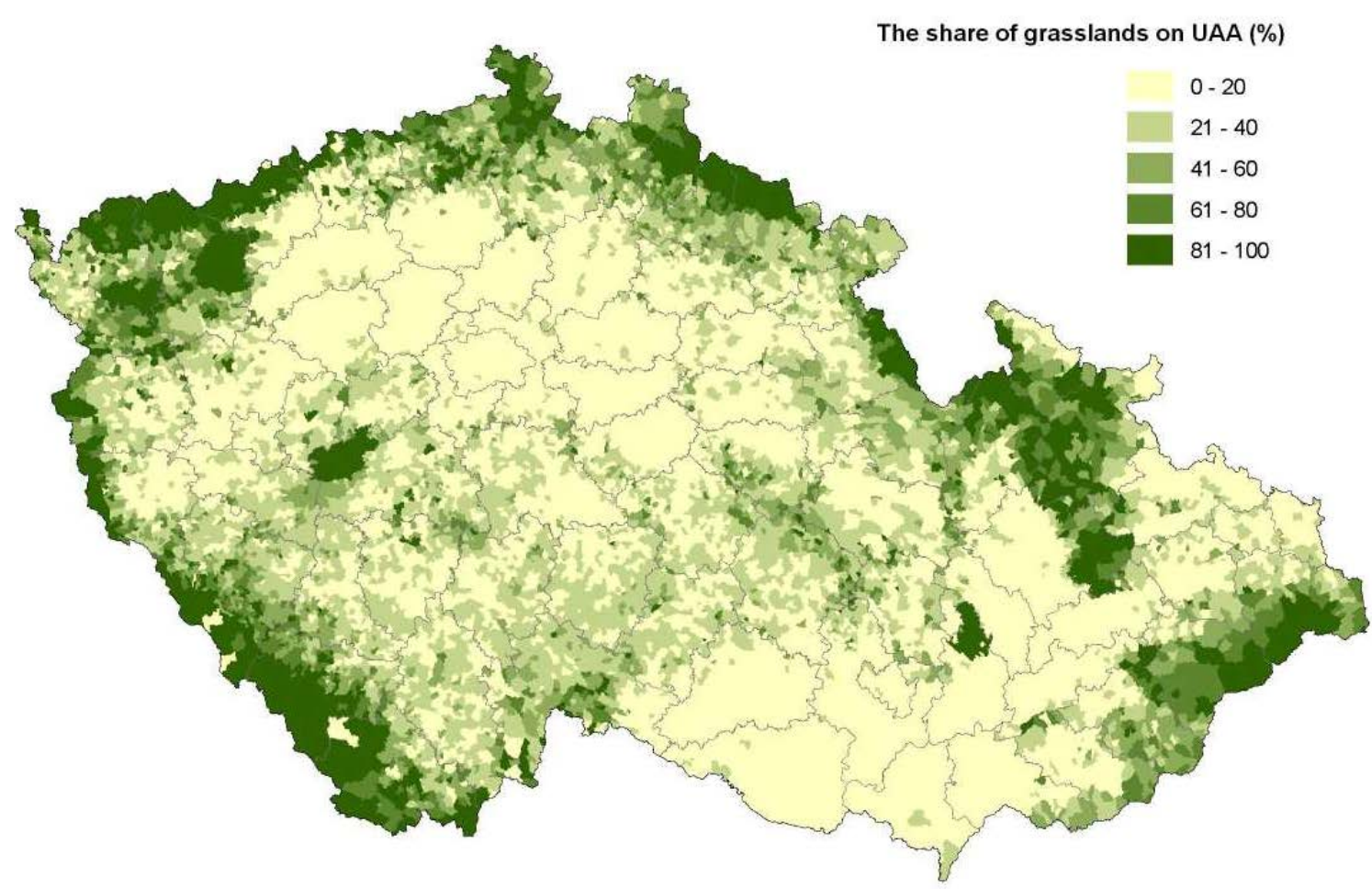

Source: LPIS 2011, own processing

Figure 1 The share of grasslands on UAA

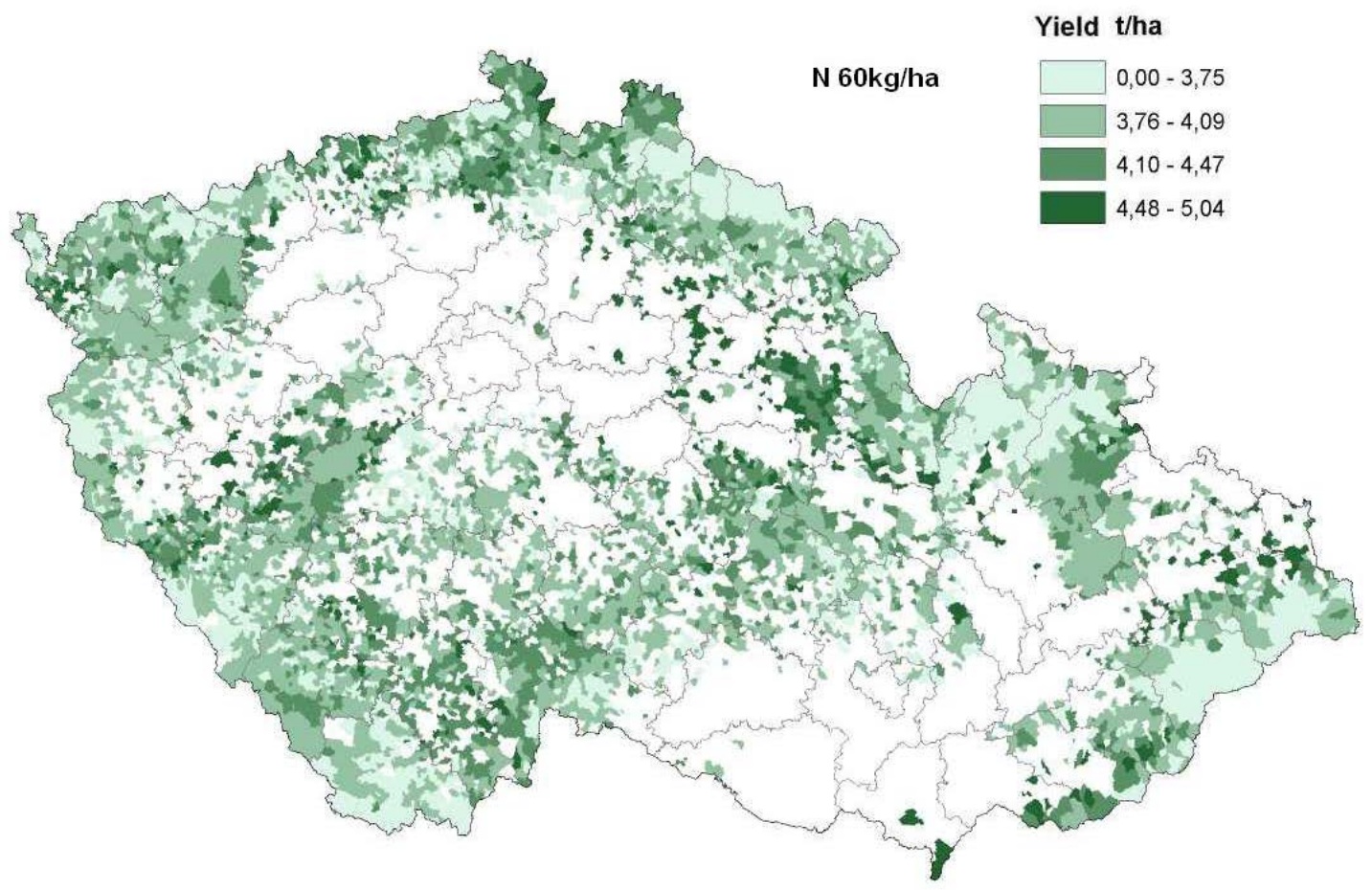

Notes: yields are displayed only for cadastres with more than $20 \%$ of grasslands.

Source: Voltr et al. 2011

Figure 2 Distribution of grass yields (in hay equivalent) 
Table 1 Cattle herd ('000 head) development

\begin{tabular}{lccccccccccccc}
\hline & 2000 & 2001 & 2002 & 2003 & 2004 & 2005 & 2006 & 2007 & 2008 & 2009 & 2010 & 2011 & 2012 \\
\hline Dairy cows & 548 & 529 & 496 & 466 & 437 & 433 & 432 & 410 & 403 & 394 & 378 & 374 & 369 \\
Suckler cows & 67 & 82 & 100 & 124 & 136 & 141 & 140 & 154 & 163 & 160 & 168 & 178 & 178 \\
\hline Total & 615 & 611 & 596 & 590 & 573 & 574 & 572 & 564 & 566 & 571 & 547 & 562 & 547 \\
\hline Source: CZSO, Register of production animals, Accessed on August 20, 2013
\end{tabular}

Table 2 Cost benefit analysis of beef production on grasslands (typical farm, 2012)

\begin{tabular}{|c|c|c|c|c|}
\hline \multirow[t]{2}{*}{ Item } & & \multicolumn{2}{|c|}{ Value } & \multirow{2}{*}{$\mathrm{BC}$ ratio } \\
\hline & & $\mathrm{CZK} / \mathrm{ha}$ & EUR/ha & \\
\hline Costs & Cattle, hay (cash+deprec.) & 7922 & 313.3 & \\
\hline Market earnings & Beef meat, young animals & 5989 & 236.8 & $76 \%$ \\
\hline Market earnings & Hay & 857 & 33.9 & $11 \%$ \\
\hline Market earnings & Total & 6846 & 270.7 & $86 \%$ \\
\hline \multirow[t]{7}{*}{ Support } & SAPS & 4060 & 160.5 & $51 \%$ \\
\hline & LFA Payment & 4139 & 163.7 & $52 \%$ \\
\hline & AEM + organic & 5323 & 210.5 & $67 \%$ \\
\hline & Top up UAA & 514 & 20.3 & $6 \%$ \\
\hline & Top up suckler cows & 848 & 33.5 & $11 \%$ \\
\hline & Top up livestock unit (LU) & 796 & 31.5 & $10 \%$ \\
\hline & Other national & 150 & 5.9 & $2 \%$ \\
\hline Total support & & 15830 & 626.0 & $200 \%$ \\
\hline \multirow[t]{2}{*}{ Social value } & WTP & 7483 & 296 & $94 \%$ \\
\hline & WTA & 15230 & 602 & $192 \%$ \\
\hline \multirow[t]{2}{*}{ Profit } & Market & -1076 & -43 & \\
\hline & Total & 14754 & 583 & \\
\hline
\end{tabular}

Notes: BC ratio - a benefit cost ratio

Source: own calculations

Domestic demand for beef meat is limited (9 kg/per capita and year, CZSO, 2012b) and even more for the organic one. Primary reason is high price combined with lacking beef meet cooking tradition, what discourages most of the consumers to buy meat of beef breeds. Thus the weaners ${ }^{4}$ coming from pastoral farms (either organic or not) are often sold abroad. Young stocks can find mature markets in the EU countries like Italy, Germany, Netherlands and Austria, where finishing farms can compete with much better price in comparison to the domestic farms. It is estimated that about $80 \%$ of the Czech beef breed weaners are sold for finishing abroad.

The respective support of organic beef has undaubtedly generated environmental and landscape values, while the "organic" specificity has failed to reach Czech consumers. It is in contrast to citizens' willingness to pay for grassland maintenance, especially if jointness is to exist between grasslands and pastoral beef cattle production (Pražan et al. 2006, Ratinger et al 2004, Durand, Huylenbroeck 2003). One

\footnotetext{
${ }^{4}$ Young bulls of about 9 months
}

explanations is in a lack of knowledge that "organic" means first of all protection of environment, and poor communication between organic farmers and potential consumers. Another explanation lies on the nonexclusion problem of public goods which consumers are aware of (Ratinger et al. 2004).

The cow-calf farm economics, as well as a simple cost benefit analysis is illustrated on a case study conducted in this research. The selected farm cultivates about 1500 hectares, has 420 suckler cows with the overall livestock density $0.61 \mathrm{LU} / \mathrm{ha}$. Market earnings cover just $86 \%$ of the costs. Farm receives total support which is twice higher than costs. It finally generates profit of $€ 583$ per hectare. Comparing to the average WTP and WTA estimates, the AE supports do not cover the societal ecological value of grasslands (see the discussion in the Conclusions). This is a case of a very successful farm. It is worth to stress, that the average economic results of cow-calf farms in the UZEI farm cost sample are a bit less impressive. Nevertheless, farm on average still generates substantial profit. There is however, a broad distribution of cow-calf farms in the 
sample by economic results. About a third of the beef cattle production in the sample is unprofitable.

\section{Farm Model}

To address the above issues and to assess the (private) economic viability of grassland farms under various policy scenarios we developed a set of "uniform" farm level models ${ }^{5}$. Actually it is an extension of the currently used models FARMA-4 (Foltýn et al. 2007, Ratinger et al. 2011). The farm models are linear programming models with an option of a quadratic cost function as an objective function (Positive Mathematical Programming approach, Howitt 1995). The FARMA-4 model includes potentially 23 farm enterprises (of it 15 crop and 8 animal ones) in up to 3 intensification modes. The objective function is usually gross profit. The standard model is built for three production regions labelled by dominant crop (Corn \& Sugar Beet [CSB], Cereal [CER], Potato \& Oat/Mountain [POM]). Two farm types are considered in the POM region, namely a mixed farm and a specialised pastoral cow-calf farm. The model applied in this paper does not consider SCB region, since grasslands contribution to production here is insignificant and serve mainly for environmental purposes. On the other hand, the POM region is split in Potato \& Oat [POO] and Mountain [MOU] regions. There are two farm types considered for each of these three regions - mixed farms with about 50\% of grasslands and specialised cow-calf farms with $90 \%$ of grasslands.

Maps in Figure 4 illustrate differences in grass yield among production regions (CER, POO, MOU). In order to capture location of grassland farms, we used district instead of cadastres as it is in Figure 1 and Figure 2.

Grasslands are divided into pastures and meadows. Grass from pastures can only be used for the adjacent beef production, while hay from meadows can be sold too.

There are four main sources of data: i) LPIS $^{6}$ (2011), which provides distribution of grasslands on farms and distribution of farms according to the share of grasslands, ii) grass yields and feeding quality of grass by soil quality (BPEJ, Voltr et al. 2011) and cadastre, iii) $\mathrm{FADN}^{7}$ providing production structure and economic data and finally iv) cost survey providing economic figures per enterprise (activity in model terms).

The mentioned cost survey includes only large farms of the average size of 1100 hectares. However, by analysing grassland farms in LIPS we have learned that the average size of farms with more than $90 \%$ of grasslands is 450 hectares. Thus the current model refers to large farms only. In the future we will differentiate farms also by size (i.e. a set of medium size farms will be introduced).

\section{Scenarios}

The support to grasslands will necessarily change in the next program period (2014-2020). First of all grassland

\footnotetext{
${ }^{5}$ Structurally identical.

${ }^{6}$ Land Parcel Identification System.

${ }^{7}$ Farm Data Accountancy Network.
}

maintenance will be in principle ensured by "greening" and it can be further enforced if the respective management is defined in $\mathrm{GAEC}^{8}$. Second, the current flat rate support to grasslands is defined as a compensation for reducing application of fertilisers on grasslands. Our above mentioned survey however, indicated that there is no difference in the application of fertilisers between participating and non-participating farms, which in turn means, that the base for the compensation vanishes. Thus it is likely that the AEP will be limited to high biodiversity values, located mainly (but not exclusively) in the protected areas. Third, Doucha et al. (2012b) showed, that income figures (e.g. net value added per AWU) are substantially higher for grassland farms ${ }^{9}$ in LFA than for farm in nonLFA. It is therefore likely, that LFA payments will be revised and lowered for grasslands ${ }^{10}$. Another likely change will be the extension of eligibility to all agricultural land and “degressivity” of payments with the size of recipients.

An overall decrease of the total support per hectare can be expected and in many cases the cut will be substantial. The question is, what will be the response of farmers. A gradual decrease of suckler cows will follow? Or farmers will intensify the use of grasslands in order to get additional revenue from the market? Is there a danger of grassland abandonment?

To get an insight in these issues, we defined two scenarios, a baseline one and the reductions of $\mathrm{AE}$ payments for grassland maintenance and LFA payments. Baseline refers to continuation of the current policy toward grasslands, i.e. with LFA and AE payments at the current levels, both restricted to grasslands only. Farms however, will receive direct payments (DP) at the rate defined in the legislative proposal for Pillar 1 (EC 2011a). Since the assumed farm size is 1000 hectares, the farms are not exposed to capping ${ }^{11}$.

Scenario 1 assumes a complete cut of AEP on all farms except those in mountain regions. However, in mountain regions AEP will drop to half. LFA payments are extended to all agricultural land and reduced (€25/ha in CER, €50/ha in POO, €100/ha in MOU).

Scenario 1 will be calculated in two modes. In the short term effect mode (S1s) the livestock density minimum limit is maintained. It might still be included in the conditions for LFA support; at the same time it refers to short term inflexibility to adjust the beef cattle herd. In the adjustment mode (S1a) the minimum livestock density condition has been removed. In addition, we have recalculated S1s scenario for organic cow-calf farms (S1bio).

\footnotetext{
${ }^{8}$ Good Agricultural and Environmental Conditions.

${ }^{9}$ Predominantly extensive beef cattle.

${ }^{10}$ Currently LFA payments are restricted only to grasslands.

${ }^{11}$ Subtraction of the labour cost will cause that such farms will not exceed the threshold for progressive capping.
} 
Table 3 Simulation results - cost and revenue indicators (€/ha) $90 \%$ of grasslands

\begin{tabular}{|c|c|c|c|c|c|c|c|c|c|c|c|c|c|}
\hline \multirow[b]{3}{*}{ Indicator } & & \multicolumn{3}{|c|}{ Baseline } & \multicolumn{3}{|c|}{ S1s } & \multicolumn{3}{|c|}{ S1a } & \multicolumn{3}{|c|}{ S1bio } \\
\hline & & CE & PO & $\mathrm{MO}$ & CE & PO & $\mathrm{MO}$ & CE & PO & $\mathrm{MO}$ & CE & PO & $\mathrm{MO}$ \\
\hline & & $\mathrm{R}$ & $\mathrm{O}$ & $\mathrm{U}$ & $\mathrm{R}$ & $\mathrm{O}$ & $\mathrm{U}$ & $\mathrm{R}$ & $\mathrm{O}$ & $\mathrm{U}$ & $\mathrm{R}$ & $\mathrm{O}$ & $\mathrm{U}$ \\
\hline \multirow[t]{2}{*}{ Cost } & grass & 126 & 165 & 134 & 126 & 165 & 134 & 83 & 94 & 83 & 126 & 165 & 134 \\
\hline & Beef & 275 & 248 & 248 & 275 & 248 & 248 & 144 & 132 & 127 & 330 & 297 & 297 \\
\hline \multirow{3}{*}{$\begin{array}{l}\text { Market earnings } \\
\text { Envi/landscape } \\
\text { support }\end{array}$} & beef, hay & 106 & 95 & 95 & 106 & 95 & 95 & 142 & 126 & 118 & 138 & 123 & 123 \\
\hline & DP - greening & & & & 83 & 83 & 83 & 83 & 83 & 83 & 83 & 83 & 83 \\
\hline & AEM/organic & 114 & 143 & 191 & & & & & & & 80 & 80 & 80 \\
\hline Income & $\begin{array}{l}\text { social value } \\
\text { DP -basic + }\end{array}$ & -180 & -175 & -96 & -212 & -235 & -205 & -3 & -18 & -11 & -155 & -177 & -146 \\
\hline \multirow[t]{2}{*}{ Income support } & coupled & 272 & 272 & 272 & 189 & 189 & 189 & 189 & 189 & 189 & 189 & 189 & 189 \\
\hline & LFA payment & 114 & 143 & 191 & 25 & 50 & 100 & 25 & 50 & 100 & 25 & 50 & 100 \\
\hline Income & profit & 206 & 240 & 367 & 3 & 4 & 85 & 212 & 222 & 279 & 59 & 63 & 144 \\
\hline \multicolumn{14}{|c|}{ Notes: S1s - Short term effect scenario - minimum 0.2 LU per hectare } \\
\hline \multicolumn{14}{|c|}{ S1a - Adjustment scenario - no minimum livestock density requirement } \\
\hline \multicolumn{14}{|c|}{ S1bio - recalculated S1s for organic beef farms } \\
\hline Source: own calculc & FARMA-4 model) & & & & & & & & & & & & \\
\hline
\end{tabular}

\section{RESULTS AND DISCUSSION}

Results are summarised in Table 3 and Figure 3. In Table 3 we present absolute values of grassland management in euros per hectare of grasslands ${ }^{12}$. Since we assume baseline as a continuation of the current policy, we do

not split direct payments to "greening” and basic income support as it is in the proposal of the Pillar 1 for 20142020 (European Commission 2011a). Direct payments include also coupled headage payments for cattle. Since we consider beef as well as dairy cattle on grasslands on mixed farms (50\% of grasslands), coupled payments include both coupled payments. The share of dairy farms on grasslands however, is rather small. The variation in grass yields is reflected in costs (of grass and of beef). According to the UZEI cost survey, farm revenues from the beef production in CER region ${ }^{13}$ and the other two regions slightly differ. It is likely, that there are better conditions for finishing some bulls in the CER region, while only weaners are sold from farms of the rest two regions.

According to the Czech FADN, also AE payments differ substantially among the selected three production regions. These differences are projected in the baseline (BSL). This differentiation vanishes if $\mathrm{AE}$ payments are replaced by the "green" direct payments (30\% of DP), because this is a flat rate payment for all utilised agricultural area (UAA). If costs are subtracted from the market and social-environmental remuneration of farmer's activity, the resulting income is negative.

The income support, consisting of basic direct payments and coupled payments, and LFA payments, is sufficient not only for covering the "social" production losses, but for creation of interesting profit (from a bit more than $€ 3,000$ to about $€ 400,000$ on an average cost survey farm $^{14}$ ).

Comparing the scenarios we can see, that replacement of AEM for grasslands by greening, while maintain the minimum livestock density (0.2), will deepen social value/cost unbalance. If in addition LFA payments decline, the overall business income (profit) will be marginalised on cow-calf farms on grasslands in the CER and POO regions. If it is just a short term effect, i.e. farms will be allowed to adjust livestock, then the suckler cows will go down (to half), farms will reduce fertilising grasslands and unfed grass will be sold as hay. This adjustment will improve the economics of grasslands substantially. Net income (profit) will approach the figures of the baseline.

It is likely, that organic production support will be given only to farms of a certain intensity of beef production. Hence we assume, that the minimum livestock density will be maintained as in the S1s scenario. If this support is roughly the same as at present ( $80 € / \mathrm{ha}$ ), then the economics of beef cattle grassland production will improve significantly.

The relative performance indicators,(Figure 3) refer to all farm enterprises, not just only to beefgrassland production. The change of the policy will have severe impact on farms performance if their flexibility is limited. In this case, total revenue will just cover costs. Relaxing the pressure on beef production however, will release part of the arable land for more profitable crop than fodder crop and thus will result in higher revenue per farm (market revenue will more than double). It will improve farm profitability (revenue/cost ratio). High dependence on the public supports, particularly of predominantly grassland farms, will slightly decline.

\footnotetext{
${ }^{14} 1100$ hectares. The profit interval will be roughly of half values for the average grassland farm from LPIS.

\footnotetext{
${ }^{12}$ Showed for entirely grassland farms (90\%).

${ }^{13}$ In LFA, mostly the specific ones.
} 


\section{CONCLUSIONS}

In the paper we repeatedly touched the issue of social value of grasslands. This value consists of both, the market value of the output and the environmental (nonmarket) value of grasslands as biodiversity and landscape factors. The market output includes beef and partly hay.

The assumption of jointness between pastoral beef production and the provision of the environmental values is embedded in the current definition of AEM, supporting appropriate cultivation of grasslands. Table 3 shows that

costs of cultivating grasslands by raising beef cattle exceptionally, are uncovered by market value and $\mathrm{AE}$ payments in all scenarios. We can assume however, that LFA payments are to compensate low productivity of land in areas with natural handicaps. Adding them to market earnings the relationship between "targeted" earnings and costs improves significantly (Table 4)

The cost coverage is seriously dissatisfactory in the scenario S1s. The scenario S1a indicates possible space for improving market contribution, if the level of jointness between beef production and grassland maintenance is reconsidered. Note however, that our assumption of good market for hay is too strong. In addition, arable production can be less profitable than we assume (i.e. based on the current good prices for cereals and rapeseed).

Another question is how AE supports match environmental value of grasslands assessed by the Czech citizens (Table 5). We used the average WTP and WTA figures according to Wollmuthová, Majerová (2011). Clearly, the targeted public support to grasslands is deeply below the WTP and WTA averages, close to the lower bound of the WTP estimate (€168) in the baseline and S1bio. The green part of DP is far from reflecting the citizens' valuation of grasslands.

The basic income support of DP provides sufficient funds to grasslands and they finally generate profit in all scenarios. This profit is substantial in most cases except for CER and POO regions in S1s scenario.

There are two issues associated with this result, i) basic direct payment is fully decoupled, hence hardly to be considered as a support to maintenance of grasslands, while the cultivation of grasslands depends on a support; ii) all the supports together are rather too generous (except the already mentioned two cases).

Another critical point is the size of farms. If farms are smaller, costs are likely higher (at least labour can be used more efficiently on the large beef-grassland farms).

In both cases, with and without of economy of scale, profits accumulated from direct payments on large farms will be substantial. Obviously, capping as originally proposed in the Commission's Communication (European Commission, 2010) will be a relevant approach, but it seems, that effective capping will not be introduced. The EU Member States might introduce degressivity by size of LFA payments, which might be effective for reducing excessive profits. Though, it will be an illogical way. The problem does not rest in possibly inappropriate compensations of handicaps, but in a provision of basic income support as a flat rate area payment.

While the model calculations show that the response of farmers will likely be lowering production intensity, the case studies, we conducted in the framework of this research, indicate opposite reaction. In the both cases, the interviewed farmers (a medium farm with acreage 600 hectares and a large farm with acreage 1800 hectares) indicated their intention to increase their suckler cow herd, in order to compensate loss of some supports in the future programme period by higher market returns. It is worth to add, that both farmers have already settled their marketing channels and get the price for beef substantially above the national average. The message of it is that we have to further improve the model to be able to capture both ways of farmers' response to envisaged policy change.

Table 4 Cost coverage by market and environmental policy earnings.

\begin{tabular}{|c|c|c|c|c|c|c|c|c|c|c|}
\hline & & \multicolumn{3}{|c|}{ Baseline } & \multicolumn{3}{|c|}{ S1s } & \multicolumn{3}{|c|}{ S1a } \\
\hline & & CER & $\mathrm{POO}$ & MOU & CER & $\mathrm{POO}$ & MOU & CER & $\mathrm{POO}$ & MOU \\
\hline Market + LFA payments,+ coupled DP & $€ /$ ha & 242 & 259 & 308 & 153 & 167 & 217 & 189 & 198 & 240 \\
\hline Compensation of envi value & $€ /$ ha & 114 & 143 & 191 & 83 & 83 & 83 & 83 & 83 & 83 \\
\hline Cost coverage & $\%$ & $89 \%$ & $98 \%$ & $131 \%$ & $59 \%$ & $60 \%$ & $78 \%$ & $120 \%$ & $124 \%$ & $153 \%$ \\
\hline
\end{tabular}


Table 5 The societal environmental value of grasslands and the policy supports (€/ha)

\begin{tabular}{llrrrrrr}
\hline & \multicolumn{4}{c}{ Baseline } & \multirow{2}{*}{ S1s,a } & S1bio \\
\cline { 3 - 6 } & & CER & POO & MOU & All & All \\
\hline \multirow{2}{*}{ Social value } & WTP & 296 & 296 & 296 & 296 & 296 \\
& WTA & 602 & 602 & 602 & 602 & 602 \\
AE supports & DP-Greening & & & & 83 & 83 \\
& AEM/organic & 114 & 143 & 191 & & 80 \\
& Total & 114 & 143 & 191 & 83 & 163 \\
\hline Source: own calculations & & & & &
\end{tabular}

$90 \%$ of grasslands

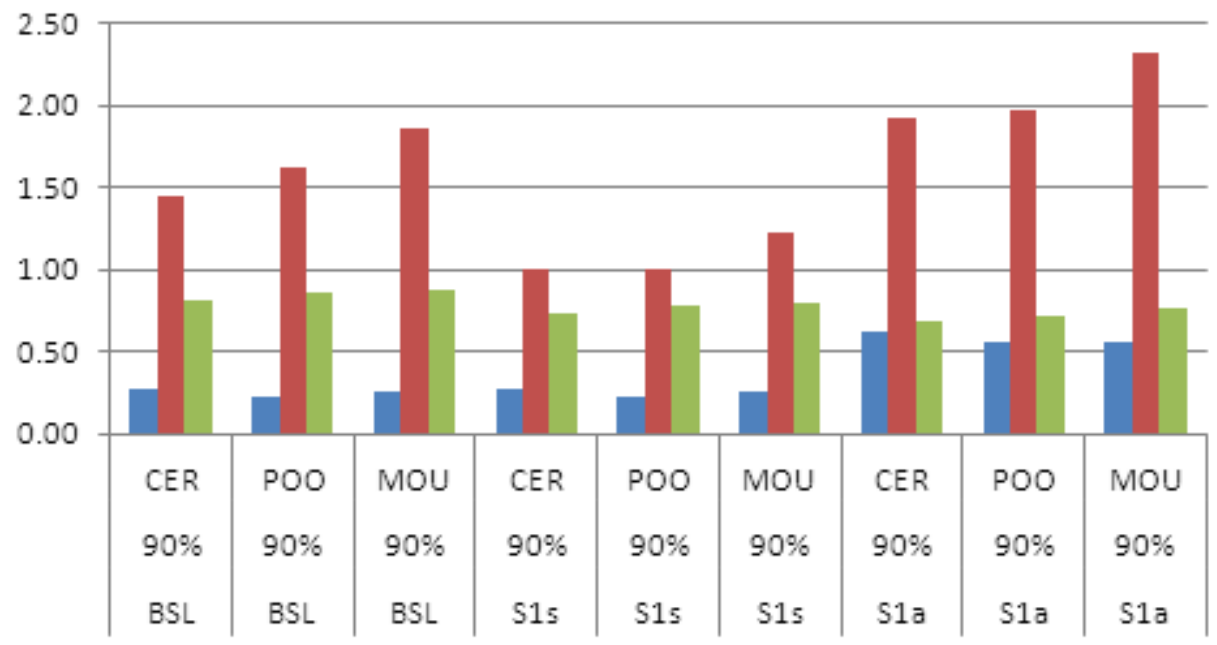

narket revenue/Costs - Total revenue/Costs a Supports/Total revenue

$50 \%$ of grasslands

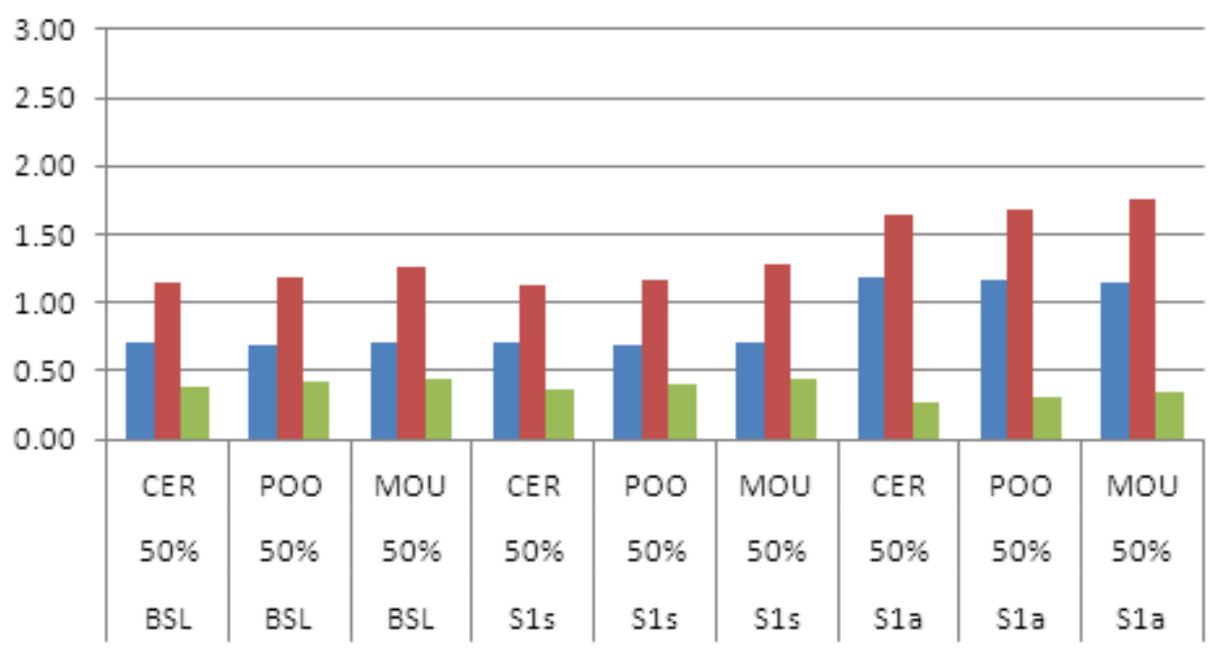

narket revenue/Costs Total revenue/Costs a Supports/Total revenue

Source: own calculations (the model FARMA-4)

Figure 3 Results of scenarios - performance indicators 


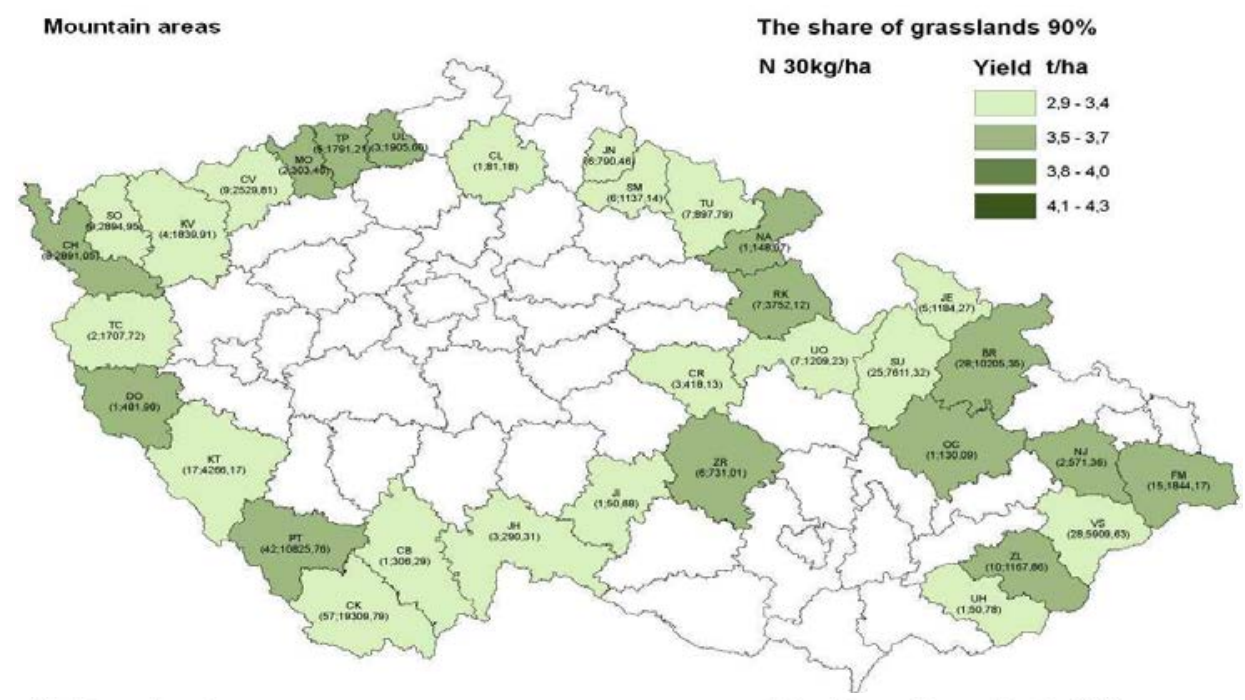

Potato-oat region

The share of grasslands $90 \%$

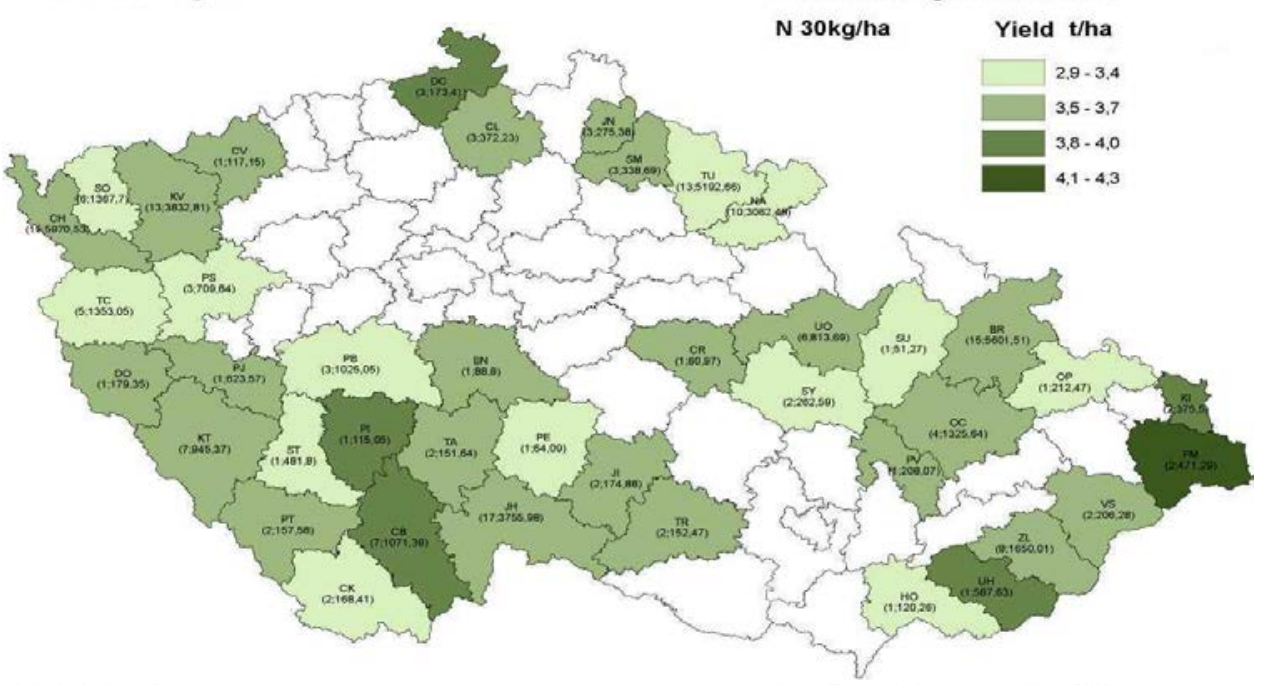

Cereal region

The share of grasslands $90 \%$

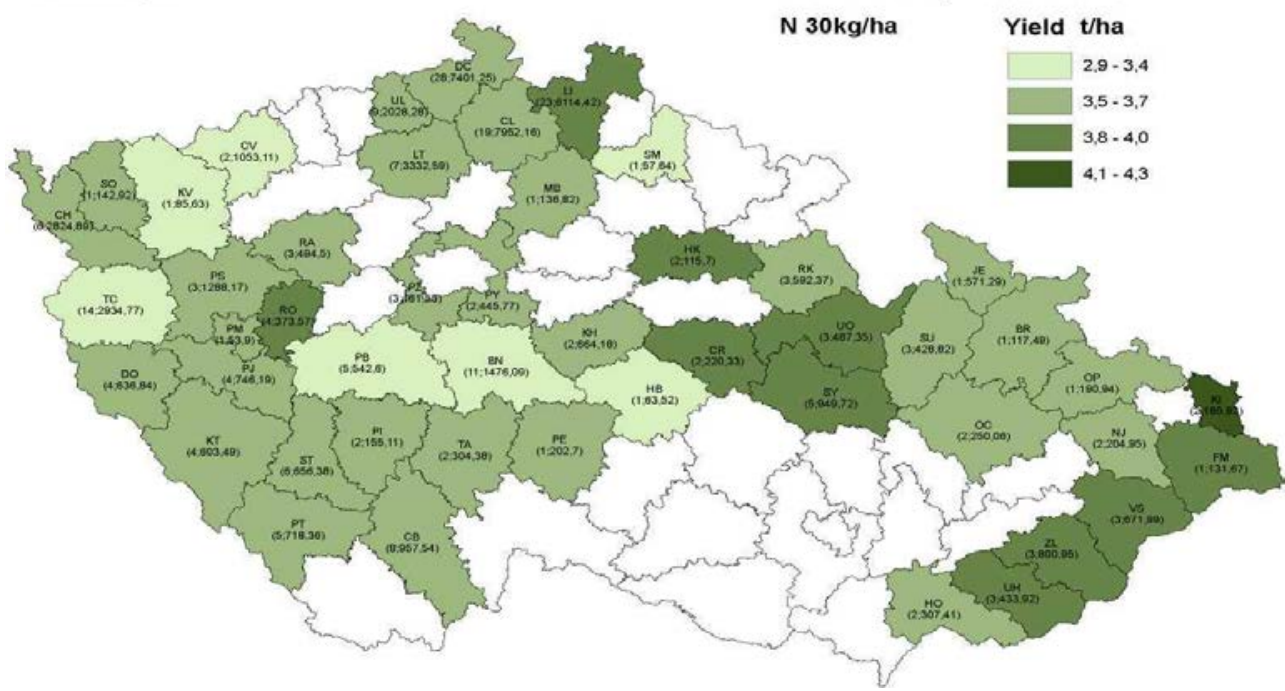

Source: own maps based on Voltr et al. 2011.

Figure 4 Average grass yield and number of farms in FADN 
Acknowledgments This paper refers to the research carried out in the framework of the Institutional Support to Research Institutions No. RO1312, "Multifunctional Agriculture for Society and Rural development” and the research grant of CZERA project of the Ministry of Education, Youth and Sports (2010-2015, LM 2010010.

\section{REFERENCES}

CZSO (2012a). Land Use. Czech Statistical Office. http://www.czso.cz/eng/redakce.nsf/i/land_use

(accessed on 5 April 2012)

CZSO (2012b) Living conditions, household income and expenditure. The Czech Statistical Office. http://www.czso.cz/eng/redakce.nsf/i/living_conditions household income and expenditure stat (accessed on 5 April 2012)

CZSO (2012c). Agrocenzus 2010 - strukturální šetření $v$ zemédělství a metody zemédělské výroby. Available in Czech only. Czech Statistical Office.. http://www.czso.cz/csu/2011edicniplan.nsf/p/2126-11

(accessed on 5 April 2012)

DOUCHA, T., FOLTÝN, I, HUMPÁL, J. (2012a) Profitability of dairy and suckler cow breeding on Czech farms. Agricultural Economics (Czech), 58 (9): 397-408.

DOUCHA, T., ŠTOLBOVÁ, M., LEKEŠOVÁ, M. (2012b) Assessment of support for farms in the Czech less favoured areas with special regards to cattle breeding. European Countryside, vol. 4, issue 3, pages 179-191

DURAND, G., VAN HUYLENBROECK, G. (2003): Multifunctional agriculture: a new paradigm for European agriculture. In Durand, G., Van Huylenbroeck (eds) Multifunctional Agriculture: a New Paradigm for European Agriculture and Rural Development. Ashgate, Aldershot, 2004. ISBN: 07546-3576-7, 256 pp

EUROPEAN COUNCIL (2009) Regulation establishing common rules for direct support schemes for farmers under the common agricultural policy and establishing certain support schemes for farmers. (EC) No 73/2009

EUROPEAN COMMISSION (2010) Communication from the Commission, 'The CAP towards 2020: Meeting the food, natural resources and territorial challenges of the future'. COM (2010) 0672

EUROPEAN COMMISSION (2011a) Regulation of the European Parliament and of the Council establishing rules for DP to farmers under support schemes within the framework of the CAP. COM (2011) 625/3 12.10.2011: http://ec.europa.eu/agriculture/cap-post2013/legal-proposals/index en.htm

EUROPEAN COMMISSION (2011b) Regulation of the European Parliament and of the Council on support for rural development by the European Agricultural Fund for Rural Development (EAFRD). COM (2011) 627/3 12.10.2011: http://ec.europa.eu/agriculture/cap-post2013/legal-proposals/index_en.htm
FOLTÝN, I., ZEDNÍČKOVÁ, I., KOPEČEK, P., KUBÁT, J. (2007) Mathematical Modelling of Sustainability in the Czech Agriculture, the paper presented at the VI AIEA2 International Conference at the XLV SOBER Congress, Londrína, Paraná, Brazílie,, pp 20.

GUESS, G. M., FARNHAM, P. G. (2000) Cases in Public Policy Analysis. Gorgetown University Press, pp. 360

HOWITT, R. E. (1995). Positive mathematical programming. American Journal of Agricultural Economics. 77. 329-342.

MOA (2012) Report on the state of Czech Agriculture in 2011 (in Czech only). Ministry of Agriculture, pp 176

PRAŽAN, J., KONEČNÁ, M., SVOBODOVÁ, M., MAJEROVÁ, J. (2011) Př́pravy obsahu AEO v rámci PRV 2014-20. (A Preparation of AEM of the Rural Development Plan 2014-20). In Czech only. Report of the MZE TU 43 /2011. ÚZEI Praha, pp. 66.

PRAŽAN, J., RATINGER, T., KŘ́MALOVÁ, V. (2005)The evolution of nature conservation policy in the Czech Republic_challenges of Europeanisation in the White Carpathians Protected Landscape Area. Land Use Policy, Volume 22, Issue 3, 235-243

RATINGER, T., KŘŮMALOVÁ, V., PRAŽAN, J. (2004) Institutions and policies for Sustainable Land Management in the Czech Republic. In G. Van Huylenboeck, W. Verbeke, L Lauwers (eds.) Role of Institutions in Rural Policies and Agricultural Markets. Elsevier B.V.375-389

RATINGER, T. FOLTÝN, I, HUMPÁL, J., JELÍNEK, L., KŘÍSTKOVÁ, Z, (2011) Podklady pro pozici MZe pro vyjednáváni o finanční perspektivě EU na obdobi 2014 - 2020 (An analysis for the position of the MA for the financial perspective negotiations. Only in Czech). Report on the Phase I. UZEI

DOUCHA, T., ŠTOLBOVÁ, M., LEKEŠOVÁ, M. (2012) Assessment of support for farms in the Czech less favoured areas with special regards to cattle breeding. European Countryside, vol. 4, issue 3, pages 179-191

VOLTR, V. ET AL. (2011) Hodnoceni půdy v podmínkách ochrany životního prostředí, (Land value in the context of environmental protection) ÚZEI, monografie, výstup z projektu NAZV QH 722257, ISBN 978-80-86671-86-4

WOLLMUTHOVÁ, MAJEROVÁ, J. (2011) An assessment of the value of agricultural landscape. The final report of the task 4.1. of the national project “Multifunctional Agriculture” MZE0002725101. Pp. 50 